\title{
Renal Handling of Sodium in Premature and Full-Term Neonates: a Study Using Clearance Methods during Water Diuresis
}

\author{
JUAN RODRIGGUEZ-SORIANO, ${ }^{(37)}$ ALFREDO VALLO, ROBERTO OLIVEROS, AND \\ GONZALO CASTILLO \\ Division of Pediatric Nephrology, Department of Pediatrics, Hospital Infantil de la Seguridad Social and \\ University School of Medicine, Bilbao, Spain
}

\begin{abstract}
Summary
A study using fractional clearances during orally induced water diuresis was designed to delineate the mechanism underlying defective tubular reabsorption of sodium in very low-birth-weight neonates. The use of clearance methodology during maximal water diuresis may give an indirect estimate of distal sodium delivery [urine volume $(\mathrm{V}), \mathrm{C}_{\mathrm{H}_{2} \mathrm{O}}+\mathrm{C}_{\mathrm{Na}+\mathrm{K}}$, , sodium reabsorption at the diluting segments $\left(\mathrm{C}_{\mathrm{H}_{2} \mathrm{O}}\right)$, and proportion of the distal load reabsorbed distally $\left(\mathrm{C}_{\mathrm{H}_{2} \mathrm{O}} / \mathrm{C}_{\mathrm{H}_{2} \mathrm{O}}+\mathrm{C}_{\mathrm{Na}+\mathrm{K}}\right)$, when all values are corrected to $100 \mathrm{ml}$ glomerular filtration rate.

The study was carried out in 28 healthy newborn infants who were grouped according to conceptual age (CA): 13 infants with mean birth weight of $1370 \pm 330 \mathrm{~g}$ and mean $\mathrm{CA}$ of $31.8 \mathrm{wk}$ (range, 28-34 wk), and 15 infants with mean birth weight of $2330 \pm 550 \mathrm{~g}$ and mean CA of 37.9 wk (range, 35-41 wk). All studies were performed at 6-7 days of age. It was demonstrated that higher urinary osmolality $(67.5 \pm 23.2$ versus $52.9 \pm 9.4$ $\mathrm{mOsm} / \mathrm{kg}, P<0.0025)$ and higher fractional sodium excretion $(2.3 \pm 1.8$ versus $0.9 \pm 0.5 \mathrm{ml} / \mathrm{dl}$ glomerular filtration, $P<0.01)$ observed in the group of very preterm infants resulted from significantly decreased proximal $(V: 18.7 \pm 6.0$ versus $13.3 \pm 3.6$ $\mathrm{ml} / \mathrm{dl}$ glomerular filtration, $P<0.005 ; \mathrm{C}_{\mathrm{H}_{2} \mathrm{O}}+\mathrm{C}_{\mathrm{Na}+\mathrm{K}}: 17.1 \pm 5.2$ versus $11.9 \pm 3.3 \mathrm{ml} / \mathrm{dl}$ glomerular filtration, $P<0.005)$ and distal $\left(\mathrm{C}_{\mathrm{H}_{2} \mathrm{O}} / \mathrm{C}_{\mathrm{H}_{2} \mathrm{O}}+\mathrm{C}_{\mathrm{Na}+\mathrm{K}} \times 100: 81.9 \pm 8.2\right.$ versus $88.2 \pm 4.5 \%$, $P<0.01)$ tubular sodium reabsorption. Distal sodium delivery correlated significantly and inversely with $\mathrm{CA}$ when all subjects were considered, but when correlations were assessed separately in each group, only in the group of very preterm infants were significant correlations present between $\mathrm{CA}$ and urinary osmolality, sodium and chloride clearances, and percentage of distal sodium reabsorption.

These results suggest that the urinary sodium loss observed in very preterm infants depends on the incapacity of the distal tubule to cope with the arrival of an increased fractional load of sodium. A modest defect in urinary dilution is observed as an obligatory consequence.
\end{abstract}

\section{Abbreviations}

CA, conceptual age

GFR, glomerular filtration rate

$\mathrm{V}$, urine volume

One of the important recent advances in neonatal renal physiology has been the demonstration that very low-birth-weight infants are unable to maintain sodium balance on a standard salt intake $(13,15,19,26,31)$. This phenomenon is due to a greater basal excretion of sodium that improves significantly with increasing gestational $(2,5,15,27)$ or postnatal age $(2,7,19,25$, 31,32 ). The mechanism for such impaired sodium conservation in very preterm infants has not been completely elucidated but inability of either the proximal or distal parts of the nephron, or of both, to reabsorb sodium efficiently might be responsible $(8$, $32,34)$.

Clearance methodology during water diuresis, although limited by the necessity for invoking a variety of assumptions, is a well accepted means to approach in vivo tubular handling of glomerular filtrate (12). In the present study such methodology has been used to assess maturation of tubular handling of sodium in newborn infants. Our results confirm the previous suggestion $(32,34)$ that the urinary sodium loss observed in very preterm infants depends not only on increased distal sodium delivery but also, and principally, on a distal tubular defect in sodium reabsorption.

\section{MATERIALS AND METHODS}

The study was performed in 28 healthy newborn infants who were grouped according to CA: 13 infants with mean birth weight of $1370 \pm 330 \mathrm{~g}$ and mean CA of $31.8 \mathrm{wk}$ (range, 28-34 wk), and 15 infants with mean birth weight of $2330 \pm 550 \mathrm{~g}$ and mean CA of 37.9 wk (range, 35-41 wk). This distribution was based on current concepts of developmental renal physiology (16). The CA was calculated adding the postnatal age to the gestational age, judged from the menstrual history of of the mother and confirmed by physical examination of the infants. All studies were performed at 6-7 days of age. The perinatal course remained uneventful, that is, was not complicated by hypoxia, respiratory distress, exchange transfusions, or serious infections. All infants were fed on breast milk. The mothers had been on normal diets and had not received diuretic therapy. In every case a parental informed consent was obtained.

The studies were carried out in the morning, without altering the ordinary feeding pattern. Each infant received a continuous gastric drip of $0.33 \%$ saline at a rate of $4 \mathrm{ml} \cdot \mathrm{min}^{-1} \cdot 1.73 \mathrm{~m}^{-2}$ over a period of $90 \mathrm{~min}$. The spontaneously voided urine was collected in plastic bags during a period of $2 \mathrm{~h}$. No bladder catheterization was necessary because results are factored by GFR so that accurately timed urine collections are not mandatory. GFR was determined by endogenous creatinine clearance and, to obviate the inaccuracy of individual periods, only the average value for all collecting periods was considered. Two capillary blood samples were taken at the beginning and at the end of the study and estimated serum values at the midpoint of each urine collection were used for clearance calculations.

Creatinine was analyzed in serum and urine using a kinetic 
Table 1. Summary of biochemical data in serum during water diuresis (mean \pm S.D.) ${ }^{1}$

\begin{tabular}{lccc}
\hline & $\begin{array}{c}\text { Infants } \\
<35 \text { wk CA } \\
(n=13)\end{array}$ & $\begin{array}{c}\text { Infants } \\
\$ 35 \text { wk CA } \\
(n=15)\end{array}$ & \\
\hline $\mathrm{Na}$ (mmole/liter) & $137.5 \pm 6.0$ & $140.3 \pm 4.2$ & $\mathrm{NS}$ \\
$\mathrm{K}$ (mmole/liter) & $5.08 \pm 0.75$ & $4.91 \pm 0.46$ & $\mathrm{NS}$ \\
$\mathrm{Cl}$ (mmole/liter) & $110.1 \pm 11.8$ & $112.3 \pm 5.3$ & $\mathrm{NS}$ \\
Osmolality & $282.2 \pm 8.5$ & $280.5 \pm 7.6$ & $\mathrm{NS}$ \\
$\quad$ (mOsm/kg) & & & \\
\hline
\end{tabular}

' Abbreviations: CA, conceptual age and NS, not significant.

approach to the Jaffe reaction (Beckman creatinine analyzer). With this method, serum creatinine represents a valid marker of renal function in newborn infants older than 4-5 days $(17,36)$. Serum and urine osmolality were determined by freezing-point depression using an Advanced Osmometer. Sodium and potassium concentration were measured by flame photometry and chloride concentration by potentiometric titration using a $\mathrm{Ra}$ diometer chloridometer.

Clearance methodology used for study of tubular function was in accord with current knowledge (12). Osmolar $\left(\mathrm{C}_{\mathrm{osm}}\right)$, sodium $\left(\mathrm{C}_{\mathrm{Na}}\right)$, chloride $\left(\mathrm{C}_{\mathrm{Cl}}\right)$, and potassium $\left(\mathrm{C}_{\mathrm{K}}\right)$ clearances were calculated by standard formula. Free water clearance $\left(\mathrm{C}_{\mathrm{H}_{2} \mathrm{O}}\right)$ was derived from: $\mathrm{C}_{\mathrm{H}_{2} \mathrm{O}}=\mathrm{V}-\mathrm{C}_{\mathrm{osm}}$, where $\mathrm{V}$ stands for diuresis. During maximal water diuresis, $\mathrm{C}_{\mathrm{H}_{2} \mathrm{O}}$ approximates the reabsorption of $\mathrm{NaCl}$ at the distal diluting segments of the nephron, $\mathrm{V}$ represents the fraction of filtrate that reaches the ascending loop of Henle, and the calculations $\mathrm{C}_{\mathrm{H}_{2} \mathrm{O}}+\mathrm{C}_{\mathrm{Na}} \mathrm{C}_{\mathrm{H}_{2} \mathrm{O}}+\mathrm{C}_{\mathrm{Cl}}$ and $\mathrm{C}_{\mathrm{H}_{2} \mathrm{O}}$ $+\mathrm{C}_{\mathrm{Na}+\mathrm{K}}$ provide an estimation of distal $\mathrm{NaCl}$ delivery. The $\%$ of distal $\mathrm{NaCl}$ reabsorption is assessed relating distal reabsorption to distal load: $\mathrm{C}_{\mathrm{H}_{2} \mathrm{O}} / \mathrm{C}_{\mathrm{H}_{2} \mathrm{O}}+\mathrm{C}_{\mathrm{Na}}, \mathrm{C}_{\mathrm{H}_{2} \mathrm{O}} / \mathrm{C}_{\mathrm{H}_{2} \mathrm{O}}+\mathrm{C}_{\mathrm{Cl}}$ and $\mathrm{C}_{\mathrm{H}_{2} \mathrm{O}} / \mathrm{C}_{\mathrm{H}_{2} \mathrm{O}}$ $+\mathrm{C}_{\mathrm{Na}+\mathrm{K}}$.

Statistics were calculated by Student's $t$ test for unpaired data. Correlation coefficients were determined with the least-square formula. $P$ values less than 0.05 were considered significant. All values are given as mean \pm standard deviation (S.D.).

\section{RESULTS}

In Table 1 the biochemical data in serum during water diuresis are given. No statistical differences were found in osmolality and concentrations of sodium, potassium, and chloride. The values after water loading were not statistically different from the baseline values. Although no overall correlation was present between serum values and $\mathrm{CA}$, the lowest values for serum sodium tended to be observed in the more premature infants.

A summary of data for all studies are presented in Table 2. In this table and in all figures, only one value, that corresponding to the period of maximal free water clearance, is considered in each subject except for values of creatinine clearance, which correspond to the average value of all collection periods. Very preterm infants (CA less than $35 \mathrm{wk}$ ) presented significantly higher values for urinary osmolality and for osmolar, sodium, potassium, and chloride clearances. Fractional urine volume and fractional distal $\mathrm{NaCl}$ delivery $\left(\mathrm{C}_{\mathrm{H}_{2} \mathrm{O}}+\mathrm{C}_{\mathrm{Na}}, \mathrm{C}_{\mathrm{H}_{2} \mathrm{O}}+\mathrm{C}_{\mathrm{Cl}}, \mathrm{C}_{\mathrm{H}_{2} \mathrm{O}}+\right.$ $\mathrm{C}_{\mathrm{Na}+\mathrm{K}}$ ) were also significantly higher in the group of more immature newborns. Although the three terms used to express distal $\mathrm{NaCl}$ delivery were almost identical, only the value of $\mathrm{C}_{\mathrm{H}_{2} \mathrm{O}}+$ $\mathrm{C}_{\mathrm{Na}+\mathrm{K}}$ will be used for correlations. The mean value of creatinine clearance in very preterm infants was $26.4 \mathrm{ml} \cdot \mathrm{min}^{-1} \cdot 1.73 \mathrm{~m}^{-2}$, significantly lower than the value found in more mature newborns of $46.4 \mathrm{ml} \cdot \mathrm{min}^{-1} \cdot 1.73 \mathrm{~m}^{-2}$. A negative correlation was present between fractional distal sodium delivery and creatinine clearance when all subjects were considered: $\mathrm{C}_{\mathrm{H}_{2} \mathrm{O}}+\mathrm{C}_{\mathrm{Na}+\mathrm{K}}(\mathrm{ml} /$ $\mathrm{dl}$ GF $)=21.3-0.18 \mathrm{Ccr}\left(\mathrm{ml} \cdot \mathrm{min}^{-1} \cdot 1.73 \mathrm{~m}^{-2}\right), r=-0.54, P<$ 0.01 .

Sodium chloride reabsorption at the diluting segments, esti-
Table 2. Summary of data from period of maximal free water clearance (mean \pm S.D. $)^{1}$

\begin{tabular}{|c|c|c|c|}
\hline & $\begin{array}{c}\text { Infants } \\
<35 \text { wk CA } \\
(n=13)\end{array}$ & $\begin{array}{c}\text { Infants } \\
>35 \text { wk CA } \\
(n=15)\end{array}$ & $P$ \\
\hline Uosm & $67.5 \pm 23.2$ & $52.9 \pm 9.4$ & $<0.0025$ \\
\hline $\mathrm{V}(\mathrm{ml} /$ & $18.7 \pm 6.0$ & 13.3 & 0.005 \\
\hline $\operatorname{Cosm}(\mathrm{ml} / 100 \mathrm{ml} \mathrm{GF})$ & $4.8 \pm 2.7$ & $2.9 \pm 1.5$ & $<0.025$ \\
\hline $\mathrm{C}_{\mathrm{H}_{2} \mathrm{O}}(\mathrm{ml} / 100 \mathrm{ml} \mathrm{GF})$ & $13.9 \pm 4.4$ & $10.9 \pm 3.1$ & $<0.025$ \\
\hline $\mathrm{C}_{\mathrm{Na}}(\mathrm{ml} / 100 \mathrm{ml} \mathrm{GF})$ & $2.3 \pm 1.8$ & $0.9 \pm 0.5$ & $<0.01$ \\
\hline $\mathrm{C}_{\mathrm{K}}(\mathrm{ml} / 100 \mathrm{ml} \mathrm{GF})$ & $23.1 \pm$ & $13.6 \pm 7.4$ & $<0.05$ \\
\hline $\mathrm{C}_{\mathrm{cl}}(\mathrm{ml} / 100 \mathrm{ml} \mathrm{GF})$ & $3.2 \pm 2.3$ & $1.0 \pm 0.4$ & $<0.0025$ \\
\hline $\mathrm{C}_{\mathrm{H}_{2} \mathrm{O}}+\mathrm{C}_{\mathrm{Na}}(\mathrm{ml} / 100 \mathrm{ml} \mathrm{C}$ & $16.2 \pm 5.7$ & $11.8 \pm 3.3$ & $<0.01$ \\
\hline$(\mathrm{ml} / 100 \mathrm{ml} \mathrm{GF})$ & $17.1 \pm 5.2$ & $11.9 \pm 3.3$ & $<0.0025$ \\
\hline $\mathrm{C}_{\mathrm{H}_{2} \mathrm{O}}+\mathrm{C}_{\mathrm{Na}+\mathrm{K}}(\mathrm{ml} / 100 \mathrm{ml} \mathrm{GF})$ & $17.1 \pm 5.5$ & $12.2 \pm 3.3$ & $<0.005$ \\
\hline $\mathrm{C}_{\mathrm{H}_{2} \mathrm{O}} / \mathrm{C}_{\mathrm{H}_{2} \mathrm{O}}+\mathrm{C}_{\mathrm{Na}} \times 100(\%)$ & $86.6 \pm 8.7$ & $92.0 \pm 3.1$ & $<0.025$ \\
\hline $\mathrm{C}_{\mathrm{H}_{2} \mathrm{O}} / \mathrm{C}_{\mathrm{H}_{2} \mathrm{O}}+\mathrm{C}_{\mathrm{Cl}} \times 100(\%)$ & $81.9 \pm 10.7$ & $91.6 \pm 2.8$ & $<0.0025$ \\
\hline $\mathrm{C}_{\mathrm{H}_{2} \mathrm{O}} / \mathrm{C}_{\mathrm{H}_{2} \mathrm{O}}+\mathrm{C}_{\mathrm{Na}+\mathrm{K}} \times 100(\%)$ & $81.9 \pm 8.2$ & $88.2 \pm 4.5$ & $<0.01$ \\
\hline $\mathrm{C}_{\mathrm{cr}}\left(\mathrm{ml} \cdot \mathrm{min}^{-1} \cdot 1.73 \mathrm{~m}^{-2}\right)$ & $26.4 \pm 10.5$ & $46.4 \pm 11.1$ & $<0.0005$ \\
\hline
\end{tabular}

'Abbreviations: Uosm, urine osmolality; $\mathrm{V}$, urine volume; Cosm, osmolar clearance; $\mathrm{C}_{\mathrm{H}_{2} \mathrm{O}}$, free water clearance; $\mathrm{C}_{\mathrm{Na}}, \mathrm{C}_{\mathrm{K}}, \mathrm{C}_{\mathrm{Cl}}$, sodium,

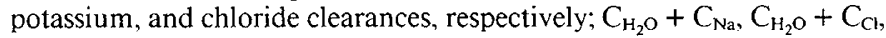

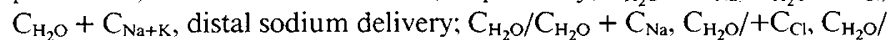
$\mathrm{C}_{\mathrm{H}_{2} \mathrm{O}}+\mathrm{C}_{\mathrm{Na}+\mathrm{K}}, \%$ of distal sodium reabsorption; and $\mathrm{C}_{\mathrm{rr}}$, creatinine clearance.

mated by the value of $\mathrm{C}_{\mathrm{H}_{2} \mathrm{O}}$, was significantly higher in the group of very preterm infants (Table 2), implying a compensatory reabsorption of the proportionally higher amount of filtrate escaping proximal reabsorption. This compensation, however, was not sufficient to reabsorb distally the same proportion of the load, and the ratios $\mathrm{C}_{\mathrm{H}_{2} \mathrm{O}} / \mathrm{C}_{\mathrm{H}_{2} \mathrm{O}}+\mathrm{C}_{\mathrm{Na}}, \mathrm{C}_{\mathrm{H}_{2} \mathrm{O}} / \mathrm{C}_{\mathrm{H}_{2} \mathrm{O}}+\mathrm{C}_{\mathrm{Cl}}$ and $\mathrm{C}_{\mathrm{H}_{2} \mathrm{O}}$ / $\mathrm{C}_{\mathrm{H}_{2} \mathrm{O}}+\mathrm{C}_{\mathrm{Na}+\mathrm{K}}$ were significantly lower in the more immature subjects. This relationship is better analyzed in Figure 1, which expresses distal sodium reabsorption $\left(\mathrm{C}_{\mathrm{H}_{2} \mathrm{O}}\right)$ as a function of distal sodium load $\left(\mathrm{C}_{\mathrm{H}_{2} \mathrm{O}}+\mathrm{C}_{\mathrm{Na}+\mathrm{K}}\right)$. It can be observed that the very preterm infants presented higher values of distal sodium delivery and higher values of free water formation, but the ratio between both variables remained below that found in more mature subjects.

When values for urinary osmolality and fractional clearances were related to $\mathrm{CA}$, no correlations were present when $\mathrm{CA}$ was at or above $35 \mathrm{wk}$, but significant correlations were present for urinary osmolality, sodium, and chloride clearances, and \% of distal sodium reabsorption when CA was less than 35 wk (Table

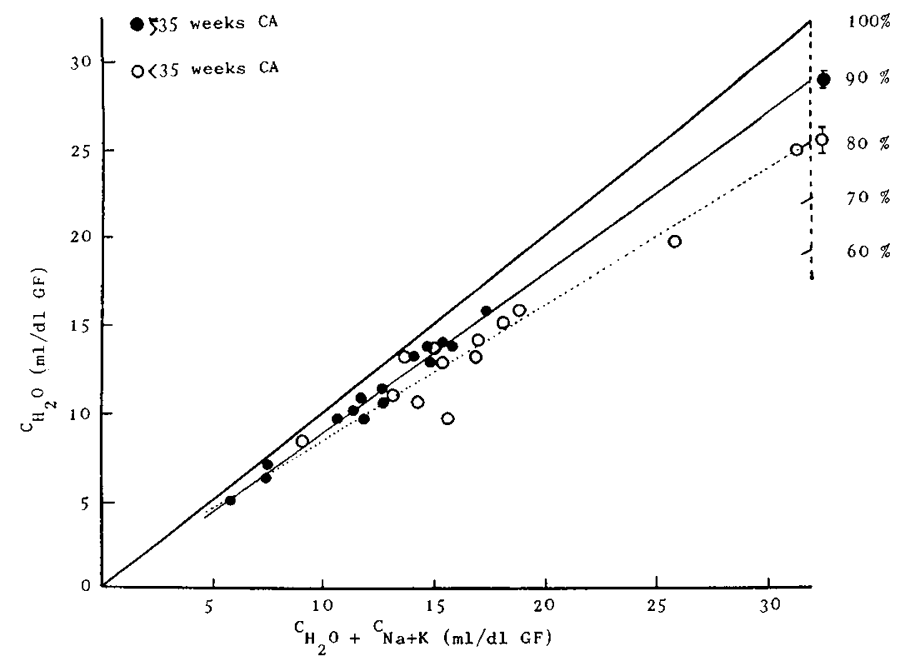

Fig. 1. Relationship between free water clearance $\left(\mathrm{C}_{\mathrm{H}_{2} \mathrm{O}}\right)$ and simultaneous fractional distal sodium delivery $\left(\mathrm{C}_{\mathrm{H}_{2} \mathrm{O}}+\mathrm{C}_{\mathrm{Na}+\mathrm{K}}\right)$. 
Table 3. Correlations between conceptual age (CA) and fractional clearances

\begin{tabular}{lccccc}
\hline & \multicolumn{2}{c}{$\begin{array}{c}\text { Infants }<35 \text { wk CA } \\
(n=13)\end{array}$} & & $\begin{array}{c}\text { Infants } \geq 35 \text { wk CA } \\
(n=15)\end{array}$ \\
\cline { 2 - 3 } \cline { 5 - 6 } & $r$ & $P$ & & $r$ & $P$ \\
\hline $\mathrm{V}$ & -0.33 & $\mathrm{NS}$ & & 0.05 & $\mathrm{NS}$ \\
Uosm & -0.76 & $<0.001$ & & -0.23 & $\mathrm{NS}$ \\
$\mathrm{C}_{\mathrm{H}_{2} \mathrm{O}}$ & -0.02 & $\mathrm{NS}$ & & -0.07 & $\mathrm{NS}$ \\
$\mathrm{C}_{\mathrm{Na}}$ & -0.56 & $<0.05$ & & -0.15 & $\mathrm{NS}$ \\
$\mathrm{C}_{\mathrm{K}}$ & -0.12 & $\mathrm{NS}$ & & -0.24 & $\mathrm{NS}$ \\
$\mathrm{C}_{\mathrm{cl}}$ & -0.59 & $<0.05$ & & -0.04 & $\mathrm{NS}$ \\
$\mathrm{C}_{\mathrm{H}_{2} \mathrm{O}}+\mathrm{C}_{\mathrm{Na}+\mathrm{K}}$ & -0.23 & $\mathrm{NS}$ & & 0.02 & $\mathrm{NS}$ \\
$\mathrm{C}_{\mathrm{H}_{2} \mathrm{O} / \mathrm{C}_{\mathrm{H}_{2} \mathrm{O}}+\mathrm{C}_{\mathrm{Na}+\mathrm{K}}}$ & -0.70 & $<0.01$ & & 0.23 & $\mathrm{NS}$ \\
\hline
\end{tabular}

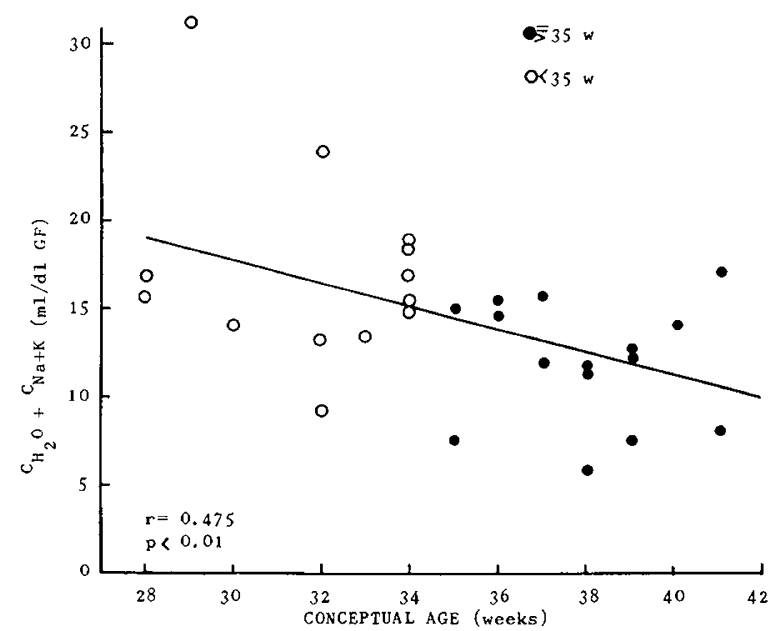

Fig. 2. Fractional distal sodium delivery $\left(\mathrm{C}_{\mathrm{H}_{2} \mathrm{O}}+\mathrm{C}_{\mathrm{Na}+\mathrm{K}}\right)$ plotted as a function of conceptual age.

3). Distal sodium delivery correlated, however, significantly with CA when all subjects were considered; that is, the more immature the subject the higher the proportion of the filtered load not reabsorbed proximally: $\mathrm{C}_{\mathrm{H}_{2} \mathrm{O}}+\mathrm{C}_{\mathrm{Na}+\mathrm{K}}(\mathrm{ml} / \mathrm{dl} \mathrm{GF})=36.9-0.64$ CA (wk), $r=-0.48, P<0.01$ (Fig. 2). Figure 3 expresses graphically the relation between the $\%$ of distal sodium reabsorption and CA: no correlation is present in the more mature subjects, but when CA is less than $35 \mathrm{wk}$, a positive correlation is present: $\mathrm{C}_{\mathrm{H}_{2} \mathrm{O}} / \mathrm{C}_{\mathrm{H}_{2} \mathrm{O}}+\mathrm{C}_{\mathrm{Na}+\mathrm{K}}(\%)=3.85+2.45 \mathrm{CA}(\mathrm{wk}), r=$ $0.70, P<0.01$.

\section{DISCUSSION}

This study using clearance methods during maximal water diuresis demonstrates the significant decrease of both proximal and distal tubular reabsorption of sodium in preterm infants born before the 34th gestational wk when compared to more mature or full-term neonates. Values for distal sodium delivery decreased significantly with advancing $\mathrm{CA}$ when all subjects were considered, whereas the $\%$ of distal sodium reabsorption only correlated significantly with $\mathrm{CA}$ in the group of very preterm infants. Incapacity of the distal tubule to cope with the arrival of an increased fractional load of sodium could explain the known inability of very immature infants to maintain sodium balance on a standard sodium intake $(13,15,19,26,31)$.

The clearance methodology used in the present study could be a matter of criticism because there is no experimental demonstration that such fractional clearances are also valid indexes of tubular function in the very immature kidney. The study, however, fulfilled all necessary requirements to assure a correct interpretation of the results. Urinary osmolality reached values as low as 67.5 and $52.9 \mathrm{mOsm} / \mathrm{kg}$ in very preterm and term infants, respectively, implying complete endogenous antidiuretic hormone suppression. This maximal water diuresis was not accomplished in two similar studies previously reported by Sulyok et al. $(32,34)$ : minimal urinary osmolality did not reach mean values below 160 and $130 \mathrm{mOsm} / \mathrm{kg}$ in premature and term infants, respectively, under a different oral hydrating protocol. Their results should be interpreted with caution because values for $\mathrm{C}_{\mathrm{H}_{2} \mathrm{O}}$ were extremely low and the physiologic interpretation of the test was therefore erroneous. Even under ideal experimental conditions, a possible error in using $\mathrm{C}_{\mathrm{H}_{2} \mathrm{O}}$ as an index of $\mathrm{NaCl}$ reabsorption in the distal nephron must be assumed because there is evidence that the distal nephron is not completely watertight even in absence of antidiuretic hormone (20). Although a lower rate of back-diffusion of water from the collecting duct in very preterm infants could theoretically account for the higher values of $\mathrm{C}_{\mathrm{H}_{2} \mathrm{O}}$, we think that improbable because the higher $\mathrm{C}_{\mathrm{H}_{2} \mathrm{O}}$ was accompanied by higher, rather than lower, values of urinary osmolality. The finding of a significant negative correlation between minimal urinary osmolality and $\mathrm{CA}$ in infants of less than $35 \mathrm{wk}$ of CA has not been previously recognized because it is accepted knowledge that urinary diluting capacity is fully developed in premature infants (22). Our data indicate, however, that very preterm infants present a small defect in urinary dilution secondary to the impairment in $\mathrm{NaCl}$ reabsorption in the distal diluting segments.

A second important requirement of this type of study is that an adequate volume of fluid must be filtered and escape proximal reabsorption to allow for maximal water diuresis (12). This is best accomplished by some degree of extracellular fluid volume expansion. Although such expansion was probably small in our protocol because it was induced by ingestion, and not by infusion, of hypotonic saline, the results are not quantitatively comparable to those previously reported by us in infants and children (24). Additional factors such as serum sodium concentration could also influence free water formation but they are not relevant to the interpretation of our results because significant hyponatremic expansion was not present (11).

The first and quantitatively most important step in the process of sodium reabsorption occurs in the proximal tubule. The present results confirm the hypothesis that in the preterm infant there is an imbalance between glomerular and tubular function with regard to the capacity to handle sodium (8). A similar imbalance has also been shown to exist for $\beta_{2}$-microglobulin, a low molecular weight protein which is constantly produced by the body, freely filtered and exclusively reabsorbed in the proximal tubule $(6,7)$. Experimental studies have demonstrated that in the immature nephron the sodium reabsorptive capacity is relatively low in the proximal tubule (19). Aperia and associates (4) have studied ultrastructural and enzymatic development of superficial proximal tubular cells of the rat nephron and have found that development of sodium reabsorptive capacity parallels



Fig. 3. Percent of distal sodium reabsorption $\left(\mathrm{C}_{\mathrm{H}_{2} \mathrm{O}} / \mathrm{C}_{\mathrm{H}_{2} \mathrm{O}}+\mathrm{C}_{\mathrm{Na}+\mathrm{K}} \times\right.$ $100)$ plotted as a function of conceptual age. 
both the ultrastructural maturation and the increase in $\mathrm{Na}-\mathrm{K}$ ATPase (10).

Although the existence in the immature kidney of a glomerulotubular imbalance is not accepted by all authors (30), Elinder et al. (14) have suggested that active renal vasoconstriction maintains GFR at low level in the perinatal period to protect the proximal tubules from overload. If an important sodium loss does not occur not only depends on that adaptative phenomenon but also, and fundamentally, because the distal tubules are able to cope with the fractional load delivered to them. There is strong evidence, both in man $(3,24)$ and in experimental animals $(9$, 21 ), that there is an enhanced reabsorptive capacity of the distal nephron for sodium during development. The enhanced distal reabsorption will also explain the blunted response to saline loading characteristic of the neonatal kidney $(1,18)$. This adaptative phenomenon appears to be absolutely necessary to maintain sodium balance (30), and may be partly induced by the observed increase in neonates of plasma renin activity and aldosterone concentration (23). The inability of very low-birthweight infants to keep the equilibrium of sodium balance could be due to inefficiency of that distal compensatory mechanism of sodium reabsorption. Although the incorrect methodology of the studies reported by Sulyok et al. $(32,34)$ have been already commented upon, these authors arrived at a similar conclusion. Whether the distal abnormality depends on an insufficient rise in aldosterone secretion or is due to a limited tubular response to aldosterone stimulation is a matter of speculation (30). The studies in the fetal lamb showing that the adrenal cortex cannot be adequately stimulated during the last trimester $(28,29)$ will favor the first possibility, but the alternative or concurrent existence of a partial unresponsiveness of the distal nephron to aldosterone is strongly suggested by the studies of Sulyok and coworkers, showing that negative sodium balance in premature infants is accompanied by high plasma renin activity and aldosterone concentration and decreased $\mathrm{K} / \mathrm{Na}$ quotient in the urine (33), and that all these abnormalities are completely reverted after $\mathrm{NaCl}$ supplementation (35).

\section{REFERENCES AND NOTES}

1. Aperia, A., Broberger, O., Thodenius, K., and Zetterström, R.: Renal response to an oral sodium load in newborn full term infants. Acta Paediatr. Scand., 61: 670 (1972).

2. Aperia, A., Broberger, O., Thodenius, K., and Zetterström, R.: Developmental study of the renal response to an oral salt load in preterm infants. Acta Paediatr. Scand, 63: 517 (1974).

3. Aperia, A., Broberger, O., Thodenius, K., and Zetterström, R.: Development of renal control of salt and fluid homeostasis during the first year of life. Acta Paediatr. Scand., 64: 393 (1975).

4. Aperia, A. and Larsson, L.: Correlation between fluid reabsorption and proximal tubule ultrastructure during development of the rat kidney. Acta Physiol. Scand., 105: 11 (1979).

5. Aperia. A., Broberger, O.. Herin, P., and Zetterström, R.: Sodium excretion in relation to sodium intake and aldosterone excretion in newborn pre-term and full-term infants. Acta Paediatr. Scand., 68: 813 (1979).

6. Aperia, A. and Broberger, U.: Beta-2-microglobulin, an indicator of the renal tubular maturation and dysfunction in the newborn. Acta Paediatr. Scand., 68: 669 (1979)

7. Aperia, A., Broberger, O., Elinder, G., Herin, P., and Zetterström, R.: Postnatal development of renal function in pre-term and full-term infants. Acta Paediatr. Scand.. 70: 183 (1981).

8. Aperia, A., Broberger, O., Elinder, G., Herin, P., Larsson, L., and Zetterström, R.: Factors governing the development of renal control of $\mathrm{Na}$ homeostasis. In: Alan B. Gruskin and Michael E. Norman Eds.: Pediatric Nephrology. pp. 273-277 (Martinus Nijhoff Publishers. The Hague, 1981).

9. Aperia, A. and Elinder, G.: Distal tubular reabsorption in the developing rat kidney. Am. J. Physiol., 240 (Renal Fluid Electrolyte Physiol. 9): F487 (1981).

10. Aperia, A., Larsson, L., and Zetterström, R.: Hormonal induction of Na-KATPase in developing proximal tubular cells. Am. J. Physiol., 241 (Renal Fluid Electrolyte Physiol. 10): F356 (1981).

11. Boornjarern, S., Stein, J. H., Baehler, R. W., Osgood, R. W., Hsueh, W., Cohen, S., Yashon, D., and Ferris, T. F.: Effect of plasma sodium concentration on diluting segment sodium reabsorption. Kidney Int., 5: 1 (1974).

12. Danovitch, G.: Clearance methodology in the study of the function of the distal tubule. Renal Physiol. (Basel), 1: 56 (1978).

13. Day, G. M., Radde, I. C., Balfe, J. W., and Chance, G. W.: Electrolyte abnormalities in very low birth weight infants. Pediatr. Res., 10: 522 (1976).

14. Elinder, G., Aperia, A., Herin, P., and Källskog, O.: Effect of the state of hydration on glomerular filtration rate and renal hemodynamics in the developing kidney. Acta Physiol. Scand., 108: 411 (1980).

15. Engelke, S. C. Shah, B. L.. Vasan, U.. and Raye, J. R.: Sodium balance in very low-birth-weight infants. J. Pediatr., 93: 837 (1978).

16. Fawer, C. L., Torrado, A., and Guignard. J. P.: Maturation of renal function in full-term and premature neonates. Helv. Paediatr. Acta, 34: 11 (1979)

17. Feldman, H. and Guignard, J. P.: Plasma creatinine in the first month of life. Arch. Dis. Child., 57: 123 (1982).

18. Goldsmith, D. I., Drukker, A., Blaufox, M. D., Edelmann, C. M. Jr., and Spitzer, A.: Hemodynamic and excretory responses of the neonatal canine kidney to acute volume expansion. Am. J. Physiol., 237 (Renal Fluid Electrolyte Physiol. 6): F392 (1979).

19. Horster, M.: Principles of nephron differentiation. Am. J. Physiol., 235 (Renal Fluid Electroyte Physiol. 4): F387 (1978)

20. Jamison, R. L., Buerkert, J., and Lacy, F.: A micropuncture study of collecting tubule function in rats with hereditary diabetes insipidus. J. Clin. Invest., 50: 2444 (1971).

21. Kleinman, L. 1.: Renal sodium reabsorption during saline loading and distal blockade in newborn dogs. Am. J. Physiol., 228: 1403 (1975).

22. Leake, R. D.: Perinatal nephrobiology: a developmental perspective. Clin. Perinatol., 4: 321 (1977)

23. Pelayo, J. C., Eisner, G. M., and José, P. A.: The ontogeny of the reninangiotensin system. Clin. Perinatol., 8: 347 (1981).

24. Rodriguez-Soriano, J., Vallo, A., Castillo, G. and Oliveros, R.: Renal handling of water and sodium in infancy and childhood: a study using clearance methods during hypotonic saline diuresis. Kidney Int., 20: 700 (1981).

25. Ross, B., Cowett, R. M., and Oh, W.: Renal function of low birth weight infants during the first two months of life. Pediatr. Res., $1 /: 1162$ (1977).

26. Roy, R. N., Chance, G. W., Radde, I. C., Hill, D. E., Willis, D. M., and Sheepers, $J_{\text {.: }}$ Late hyponatremia in very low birth weight infants $(<1.3$ kilograms). Pediatr. Res., 10: 526 (1976).

27. Siegel, S. R. and Oh, W.: Renal function as a marker of human fetal maturation. Acta Paediatr. Scand. 65: 481 (1976).

28. Siegel, S. R. and Fisher, D. A.: Ontogeny of the renin-angiotensin-aldosterone system in the fetal and newborn lamb. Pediatr. Res., 14: 99 (1980).

29. Siegel, S. R.. Oakes, G., and Palmer, S.: Transplacental transfer of aldosterone in its effects on renal function in the fetal lamb. Pediatr. Res. $15: 163$ (1981).

30. Spitzer, A.: The role of the kidney in sodium homeostasis during maturation. Kidney Int., 21: 539 (1982).

31. Sulyok, E.: Relationship between electrolyte balance and acid-base balance in the premature infant during early postnatal life. Biol. Neonate, 17: 227 (1971).

32. Sulyok, E., Varga, F., Györy, E., Jobst, K., and Csabe, I. F.: Postnatal development of renal sodium handling in premature infants. J. Pediatr., 95: 787 (1979)

33. Sulyok, E., Németh, M.. Tényi, I., Csaba. I., Györy, E., Ertl, T., and Varga. F.: Postnatal development of renin-angiotensin-aldosterone system, RAAS, in relation to electrolyte balance in premature infants. Pediatr. Res., 13: 817 (1979).

34. Sulyok, E., Varga, F., Györy, E., Jobst, K., and Csaba, I. F.: On the mechanism of renal sodium handling in newborn infants. Biol. Neonate, 37: 75 (1980).

35. Sulyok, E., Németh, M., Tényi, I., Csaba, I. F., Varga, L., and Varga, F. Relationship between postnatal development of renin-angiotensin-aldosterone system and electrolyte and acid-base status of $\mathrm{NaCl}$ supplemented premature infants. In: Adrian Spitzer Ed.: The Kidney during Development. pp. 273-281 (Masson Publishing USA Inc., New York, 1982).

36. Trompeter, R. S., Al-Dahlan, J.. Haycock, J. B., Chantler, C., Chik, G., and Stimmler, L.: Normal values for plasma creatinine concentration related to maturity in normal, term and preterm infants. Int. J. Pediatr. Nephrol., 3: 145 (1982).

37. Requests for reprints should be addressed to: Dr. J. Rodriguez-Soriano, Hospital Infantil de la Seguridad Social, Cruces, Bilbao, Spain.

38. Received for publication October 20, 1982.

39. Accepted for publication March 29, 1983. 